Атамась E.B.

\title{
Устойчивое развитие экономики: опыт Краснодарского края
}

ФГБОУ ВО «Кубанский государственный университет»

(Россия, Краснодар)

doi: $10.18411 / l j-31-10-2017-22$

idsp: 000001:lj-31-10-2017-22

\section{Аннотация}

В статье рассмотрены материалы, характеризующие вопросы устойчивого развития экономики Краснодарского края. Выделены основные направления развития экономики региона на основе концепции устойчивого развития.

Ключевые слова:устойчивое развитие территории, экономическое развитие, региональное развитие

\section{Abstract}

In article the materials characterizing questions of sustainable development of economy of the Krasnodar Territory are considered. The main directions of development of economy of the region on the basis of the concept of sustainable development are allocated.

Keywords: sustainable development of the territory, economic development, regional development

Изменение климата, нехватка ресурсов, интеграция в мировую экономику, экономические санкцииэто современная ситуация, в которой администрации региона приходится работать с 2014 года.

Рассмотрим основные два подхода к понятию «устойчивое развитие». Согласно первому - понятие «устойчивое развитие» сформировалось в конце 1960-х годовкак концепция развития мировой экономики и имеет ярко выраженный экологический характер; согласно второму подходу — это динамическое равновесие экономической системы.

Суть концепции устойчивого развития заключается втом, что рост экономики должен вписываться впределы ресурсных иэкологических возможностей территории.

Краснодарский край входит в Южный федеральный округ иСеверокавказский экономический район. Граничит с Ростовской областью, Ставропольским краем, Карачаево-Черкесской Республикой, Республикой Адыгея и Республикой Крым (через Керченский пролив). На юге проходитгосударственная граница с Абхазией.Территория Краснодарского края составляет 76 тыс. км2 (0,4\% от общей площади Российской Федерации) и имеет достаточно компактное размещение.

Отметим, что из всей наиболее существенными для региона природными ресурсамивыступают агроклиматические, почвенные, водные и лесные ресурсы, а также непосредственно связанные с перечисленными рекреационные.Заметим, что Краснодарский край имеет значительную ресурсную базу и возможности экономического развития с использованием данных ресурсов.

На протяжении многих лет существует бренд «Курорты Краснодарского края», ориентированный на внутреннего потребителя. Краснодарский край, будучи ведущим регионом в развитии туризма и курортного дела, располагает высоким природноресурсным потенциалом. Край занимает лидирующее место по численности приезжающих в рекреационных целях[1]. Для привлечения инвестиций в развитие экономики региона необходим комплекс экономических механизмов, способных оказать побудительное воздействие на потенциальных инвесторов. В связи с чем в 
Краснодарском крае разработан план мероприятий по обеспечению устойчивого развития экономики и социальной стабильности в 2016 году и на 2017 год. В данном документе отражены основные направления поддержки экономики и социальной сферы региона. Все направления выделены в две основные группы:

- неотложные мероприятия, направленные на стабилизацию социальноэкономической ситуации;

- структурные меры, направленные на обеспечение устойчивого социальноэкономического развития.

Часть направлений, представленных в плане планируется финансировать за счет федерального бюджета, но большая часть - из краевого бюджета (около 6500 млн.руб.).

Основным источником дохода для трудоспособного населения остаётсязаработная плата. Среднемесячная заработная плата работников организаций в2016 году оценивается в 28541 руб., что на 6,9\% превышает уровеньпредыдущего года. При этом отмечено сокращение уровня оплаты труда в лесномхозяйстве, производстве стройматериалов, в сфере научных исследований иразработок.

На фоне опережающего роста инфляции $(107,1 \%)$ реальная заработная платане достигла уровня 2015 года и составила 99,8\%. По состоянию на 1 января 2017 года на учёте в службе занятости населениясостояло 28,1 тыс. чел., из них 16,9 тыс. безработных граждан. Численностьбезработных по сравнению с аналогичной датой 2016 года уменьшилась на 16,4\%.Уровень регистрируемой безработицы - 0,6\% (против $0,8 \%$ годом ранее). Таким образом, мы можем сделать вывод, что занятость и постоянный доходмогут позволить семьеобеспечить более качественное образование ребенку. Данный вывод также могут подтвердить объём расходов бюджета Краснодарского края за 2016 год: наибольший удельный вес приходится на статьи «Образование» $(27,6 \%)$ и«ЗЗдравоохранениеи социальная политика» $(33,2 \%)$ [2].

Согласно постановлению главы администрации (губернатор) Краснодарского края от 5 октября 2015 г. № 939 (в ред. Постановления главы администрации (губернатора) Краснодарского края от 10.12.2015 № 1185) «Об утверждении государственной программы Краснодарского края «Развитие образования» выделены основные мероприятия направленные на развитие сети и инфраструктуры образовательных организаций, обеспечивающих доступ населения Краснодарского края к качественным услугам дошкольного, общего образования и дополнительного образования детей.

На 1 февраля 2017г. численность постоянного населения края составила 5572,5 тыс. человек, из которых 3044,0 тыс. человек $(54,6 \%)$ - горожане и 2528,5 тыс. человек $(45,4 \%)$ - сельские жители. Население края увеличилось с начала года на 1,5 тыс. человек.

В таблице 1 представлены данные естественного движения населения.

Таблийа 1

Динамика числа родившихся и умерших за 2015-2016г2,. человек

\begin{tabular}{|c|c|c|c|c|c|c|}
\hline & \multicolumn{3}{|c|}{ Число родившихся у } & \multicolumn{3}{c|}{ Число умерших } \\
\hline & 2016 год & 2015 год & Откл. & 2016 год & 2015 год & Откл. \\
\hline человек & 73806 & 74172 & -366 & 71340 & 71496 & -156 \\
\hline
\end{tabular}

Как видим в Краснодарском крае за анализируемый период демографические показатели не слишком оптимистичны, естественная убыль населения, младенческая смертность. Все показатели значительно отличаются от такого периода прошлого года.

По данным Министерства экономики Краснодарского края ВРП в 2016 году увеличился на 1\% (и составил 1983,135 млрд. рублей) по сравнению с 2015 годом. При этом в 2015 году темп роста ВРП по сравнениюс 2014 годом составлял 98,5 \%. По-нашему мнению, это было связано с перестройкой всей региональной экономики в условиях экономических санкций. 
Отметим, что по некоторым отраслям произошло снижение темпов роста, например в сфере строительства. Это связано не только с увеличением стоимости услуг строительного рынка, но и со снижением покупательской способности населения. При этом объёмы продаж пищевых продуктов, включая напитки и табак, увеличились на $0,6 \%$, а реализация непродовольственных товаров сократилась на $0,4 \%$.

Инвестиции в основной капитал, направленные на охрану окружающей среды и рациональное использование природных ресурсов в 2015 году составили 1289175 тыс. рублей, в том числе бюджетных средств -26552 тыс. рублей (федеральный бюджет). Из них направлено инвестиций на охрану и рациональное использование водных ресурсов 768083 тыс. рублей, на охрану атмосферного воздуха - 69861 тыс. рублей, на охрану и рациональное использование земель - 365933 тыс. рублей (из них 26552 тыс. рублей федеральный бюджет), на установки для утилизации и переработки отходов производства, предприятия и полигоны по утилизации, обезвреживанию и захоронению токсичных промышленных, бытовых и других отходов, охрану недр и рациональное использование минеральных ресурсов - 2236 тыс. рублей.

Для привлечения бюджетных инвестиций и стимулирования развития коммунальной инфраструктуры муниципальных образований Краснодарского края реализуется государственная программа Краснодарского края «Развитие жилищнокоммунального хозяйства», утвержденная постановлением главы администрации (губернатора) Краснодарского края от 12 октября 2015 года № 967, и вступившая в силу 1 января 2016 года со сроком реализации 2016-2021 годы [3].За счёт выделенных из краевого бюджета средств в 2016 году были выполнены работы по реконструкции участка канализационного коллектора протяженностью 507 метров (диаметр $800-1000$ мм) в городе Кореновске.Согласно информации, предоставленной администрацией муниципального образования город Краснодар, в 2016 году в городе выполнялись работы по строительству, проектированию, ремонту и содержанию очистных сооружений, канализационных и ливневых коллекторов, ливневых и фекальных канализаций, водозаборных сооружений, насосных станций на общую сумму 231,655 млн. рублей.

Как можем видеть из анализа социально-экономической составляющей развития края, необходимо развивать не только общие правила, которые защищают права человека, гарантируют занятость населения, но и обеспечивают реализацию социальных и экологических стандартов.

Экономическое развитие территории позволяетобеспечить достиженияне только в сфере экономики, политики, но и в экологической. Например, инвестиции в сферу рационального использования природных ресурсов позволятрасширить деятельность государства именно в той сфере.

Таким образом, устойчивое экономическое развитие является средством для всестороннего и широкого развития региона.

$$
* * *
$$

1. Атамась Е.В. Развитие туристско-рекреационного комплекса в Краснодарском крае // Курортнорекреационный комплекс в системе регионального развития: инновационные подходы: материалы $\mathrm{V}$ Междунар. науч.-практ. конф. Краснодар: Кубанский гос. ун-т, 2017. -С.71-74

2. Краснодарский край в цифрах [Электронный pecypc].URL.: http://economy.krasnodar.ru/macroeconomics/analiz/krasnodar-region-in-figures/ (дата обращения: 26.07.2017)

3. Государственная программа Краснодарского края «Развитие жилищно-коммунального хозяйства». Постановление главы администрации (губернатора) Краснодарского края от 12 октября 2015 года № 967. СПС «КонсультантПлюс» 